RESEARCH ARTICLES

\title{
On The Question of Studying Phraseological Units with Adjectives in the Classroom in Russian
}

\section{Sobre la cuestión de estudiar unidades fraseológicas con adjetivos en el aula en ruso}

\section{Zhang Bin}

Postgraduate student of the Department of Russian Language and Teaching Methods, Institute of Philology and Intercultural Communication, Kazan Federal University

ORCID: 0000-0002-9785-6029

\section{Yusupova Zulfiya Firdinatovna}

Head of the Department of Russian Language and Teaching Methods, Institute of Philology and Intercultural Communication, Kazan Federal University

ORCID: 0000-0002-1672-6979

\section{Yu Lui}

Lecturer, Department of Foreign Languages, Luoyang University, China

ORCID: 0000-0002-9785-6029

Received 09-08-20 Revised 10-10-20 Accepted 20-12-21 On line 03-01-21

* Correspondence

Email: zhangbin0905@gmail.com
Citation:

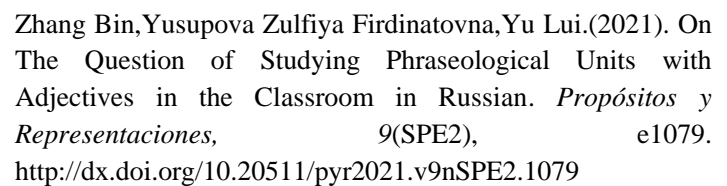




\begin{abstract}
The study of phraseological units by foreign students at the stage of their professional education is an important means of enriching students ' speech, mastering the lexical norms of the Russian language. As you know, phraseological units can contain different parts of speech, but phraseological units with adjectives have the greatest expressiveness. This research is devoted to the linguodidactic problem of developing tasks for the use of phraseological units in the speech of foreign students. To successfully achieve the research goal, we used the continuous sampling method, the analysis method, the exercise method, and the observation method. Our task was to select phraseological units with adjectives and ask Chinese students to complete tasks. Some students do not know the meaning of phraseological units and the terms of their use. At the level of professional linguistic education, students should have a good command of this material. Unfortunately, due to the complexity of the material, the form of expression, and the specifics of historical and cultural features reflected in phraseology, many students were unable to correctly determine the meaning and conditions for using the proposed phraseology. We developed a system of exercises that helped students master phraseological units with adjectives, taking into account their functioning in artistic and colloquial speech. The results of our research are of interest to teachers of Russian as a foreign language and can be used in the practice of teaching foreign languages.
\end{abstract}

Keywords: phraseological units, adjectives, Russian language, teaching, foreign students, linguodidactics.

\title{
Resumen
}

El estudio de unidades fraseológicas por estudiantes extranjeros en la etapa de su educación profesional es un medio importante para enriquecer el habla de los estudiantes, dominando las normas léxicas del idioma ruso. Como sabe, las unidades fraseológicas pueden contener diferentes partes del discurso, pero las unidades fraseológicas con adjetivos tienen la mayor expresividad. Esta investigación está dedicada a la problemática lingüística de desarrollar tareas para el uso de unidades fraseológicas en el habla de estudiantes extranjeros. Para lograr con éxito el objetivo de la investigación, utilizamos el método de muestreo continuo, el método de análisis, el método de ejercicio y el método de observación. Nuestra tarea consistía en seleccionar unidades fraseológicas con adjetivos y pedir a los estudiantes chinos que completaran tareas. Algunos estudiantes no conocen el significado de las unidades fraseológicas y los términos de su uso. A nivel de educación lingüística profesional, los estudiantes deben tener un buen dominio de este material. Desafortunadamente, debido a la complejidad del material, la forma de expresión y las características específicas históricas y culturales reflejadas en la fraseología, muchos estudiantes no pudieron determinar correctamente el significado y las condiciones para usar la fraseología propuesta. Desarrollamos un sistema de ejercicios que ayudó a los estudiantes a dominar unidades fraseológicas con adjetivos, teniendo en cuenta su funcionamiento en el habla artística y coloquial. Los resultados de nuestra investigación son de interés para los profesores de ruso como lengua extranjera y pueden utilizarse en la práctica de la enseñanza de lenguas extranjeras.

Palabras clave: unidades fraseológicas, adjetivos, lengua rusa, docencia, estudiantes extranjeros, lingüodidactica.

\section{Introduction}

In modern scientific literature, language units are studied from different sides: linguistic, linguodidactic, linguoculturological, sociolinguistic, etc. It is worth noting that the most relevant is the study of language units from the linguistic and cultural side (Azimov \& Shchukin, 2009; Shakirova et al., 2019; Mokienko, 2005; Nurullina et al., 2019; Khodyakova, 2018; Ter-Minasova, 2000; Zabuga et al., 2018; Telia, 2010) according to scientists, phraseological units have the largest number of examples that reflect the Relationship between language and culture. For example, such phraseological units as beat with a bucket, all Ivanovskoe, stand with a Firth, and Kolomenskaya verst most clearly demonstrate belonging to Russian culture, since such 
expressions are not found in other languages and cultures. However, the grammatical aspect of studying phraseological units, in particular the partial composition of expressions, is also of interest. The most common phraseological units are nouns, verbs and adjectives, numerals and pronouns. For our research, phraseological units containing adjectives were selected: Kolomna versta, White crow, Golden hand, Kazan orphan, Golden rain, Green street, etc (Telia, 2010).

The methodology for studying phraseological units in the aspect of teaching Russian with a component-the adjective name-has not been developed. Adjectives as part of phraseological turns acquire a figurative meaning, which is not always taken into account by foreign students, which leads to an erroneous understanding of this expression. We believe that it is important for students receiving professional linguistic education at the University not only to know these phraseological units, but also to learn how to use them. This research is based on the works of scientists on phraseology, grammar, linguoculturology, cognitive linguistics, as well as works on linguodidactics.

\section{Methods}

For the purposes of this study, we selected 100 phraseological units with an adjective component that are most often found in texts and textbooks. We used a continuous sampling method, an analysis method, an observation method, and an exercise method that allowed us to achieve our goal. Our goal was to offer the students the tasks that we have developed with selected expressions. This allowed us to identify the most common errors. The experimental base was the Institute of Philology and intercultural communication of Kazan Federal University. The testing of the exercises was conducted with Chinese 3rd year students-trainees who came to study Russian as part of the exchange program. We also observed the oral speech of students in Russian classes. 40 students took part in the experiment.

\section{Results}

The system of exercises developed by us is based on the following aspects, without which it is impossible to design and predict the process of teaching phraseological units to foreign (Chinese) students-trainees:

3.1 The concept of phraseological units is first given at the stage of learning Russian at the B1 level. When forming the concept of phraseological units, it is important that students understand their difference from free phrases. In addition, foreign students should understand that phraseological units are not created anew every time, but are reproduced in a ready-made form, while the component composition of phraseological units remains unchanged. Most phraseological units are not translated into other languages. They can only be compared in different languages with expressions that are equivalent in meaning (Rakhimova et al., 2019; Xiaoxu et al., 2019; A Chupryakova et al., 2019; Gok et al., 2019).

3.2. As you know, the ways of semanticizing phraseological turns are carried out by the following means of the Russian language:

1) replacing phraseology with a single word: in between-along the way; circumvent-deftly;

2) selection of synonyms: a little light - with the first roosters; breakneck-breakneck;

3) selection of antonyms: late sleeves-rolled up sleeves.

3.3. Phraseological units are present in every language, they are a bundle of national culture. The study of phraseological units is one of the means of familiarizing a native speaker with the origins and spiritual culture. Phraseology reflects the world of feelings, images and shades of a particular people. Correct and correct use of phraseological phrases gives speech brevity, imagery, brightness and expressiveness. In connection with the study of phraseological expressions in the national-cultural aspect, the concept of "phraseological picture of the world"appeared in the linguistic literature. There are various approaches to understanding the phraseological picture of the world, which are reduced to understanding that the basis of the 
phraseological picture of the world is an imaginative worldview formed in the process of collective centuries-old understanding and transformation of the environment by man. When we study phraseological units, we perceive a phraseological picture of the world that is anthropocentric and human-oriented.

3.3. Many Russian idioms talk about different sides of life of the Russian people, evidence of some historical, social and other events or phenomena.

3.4. Linguistic dictionaries, including phraseological dictionaries, play an important role in improving the level of General and speech culture of students. When teaching the Russian language, it is important to form a lexicographic culture among them. The ability to purposefully use various phraseological dictionaries to clarify, explain, compare, and accurately translate expressions is one of the important skills of students, since without it is impossible to master professional vocabulary, scientific terminology, and study any language (both Russian, native, and foreign).

When studying phraseological units, dictionaries should become a reference book for students for quantitative and qualitative enrichment of the vocabulary, for making speech figurative. When using phraseological units, you must learn to use them in accordance with the communication situation. Working in pairs, students can not only write out phraseological units, but also find synonymous, antonymous pairs; stylistic colored and neutral phraseological units, make sentences and analyze them.

System of exercises for the study of phraseological units with an adjective component:

Task 1. correlate these phraseological units with the prototypes shown below. Expand the meaning of phraseological units and give situations in which they can be used. If this is difficult for you, consult the dictionary.

A) phraseological units: a deaf Blackbird, not worth a damn, a red line.

B) prototypes: hairdressing; animal world; plant world; fishing; children's games; monetary system; Russian literacy.

Task 2. Read the phraseological units and determine their meaning. What words in phraseological units confirm their belonging to Russian culture? Check the meaning of these words in dictionaries.

Kolomenskaya versta, all the way to Ivanovo, grated roll, oblique fathom on the shoulders.

Task 3. Prove that not all of these phrases can be attributed to the phraseology. Check for yourself about the phraseological dictionary. What is the meaning of the word red in Russian? In what sense is it used as part of phraseological units? If this is difficult for you, consult the dictionary.

Red price, red fish, red rope, red maiden, red well done, red sun, Red Army, red tie, Red banner, red wine, red speeches.

Task 4. Read an excerpt from S. G. Ter-Minasova's book "War and the world of languages and cultures". Compare the use and meaning of the word red in Russian and Chinese cultures. Remember and write down Russian phraseological units with the word red.

... The cultural connotations of red in China are happiness, luck, and everything associated with it. Their origin was the worship of the ancient Chinese Sun as the source of life on earth, and the sun - the red color. Therefore, red is the main color of Chinese culture, and everything good is connected with it. It symbolizes success, wealth, quiet and sweet life.

A red man is someone who is valued by the authorities.

Red-haired singer, artist, artist-someone who instantly became famous and popular.

Red profit-bonus, increase, dividends. 
A redhead is called a young elegant girl.

Red polka dots are a symbol of love.

Red paper bag-money, monetary reward (from the tradition in the past, when at the end of the year it was customary to give money to distinguished and diligent workers in a red bag) (TerMinasova, 2000).

Task 5. Read an excerpt from the book by V. V. Vorobyov and L. G. Sayakhova " the Russian language in the dialogue of cultures "and define the concept of " phraseological picture of the world".

... Phraseology of the Russian language captures the huge diversity of the world of human relations. About 1500 phraseological units in the dictionary-reference of R. I. Yarantsev "Russian phraseology" are divided into sections:"emotions and feelings of a person","properties of a person and qualities of his character","characteristics of phenomena and situations". There is happiness, love, surprise, ridicule, indignation, interest, anxiety, suffering; these are the characteristics of a person such as directness, willpower, honesty, kindness, intelligence, dexterity, energy, perseverance, as well as stupidity, talkativeness, avarice, anger - that is, all the negative and positive properties of a person; these are the characteristics of such phenomena as similarity and difference, beginning and end, multiplicity and minority, unity - disagreement and struggle; birth, kinship, age, death; evaluation, success - failure, truth and deception, order and disorder, prosperity and poverty, mistakes and punishments, and much more. As we can see, a whole phraseological picture of the world opens up before us (Vorobyov, Sayakhova).

Task 6. Read the phraseological units and determine their meaning. What historical events gave rise to these phraseologisms? In what modern situations can they be used? If this is difficult for you, consult the dictionary.

The Kazan orphan; Mamai; the Potemkin village; a useless scrap of paper; all of Ivanovo.

Task 7. Read the text and name the phraseology, the origin of which is stated in the text. Make sentences with the correct phraseology. If you find it difficult, consult the dictionary.

In the XVII century, Tsar Alexey Mikhailovich placed high stone pillars that marked versts on the road from Moscow to the village of Kolomenskoye, where his summer residence was. In Russia, for the first time, the length was indicated by milestones, but since there was no unified system of measures at that time, Alexey Mikhailovich determined the length of a verst at seven hundred fathoms. Kolomenskaya versta firmly established in the vernacular. So jokingly called a very tall, clumsy person (Telia, 2010).

\section{Summary}

Our research has shown that figurative use of adjectives as part of phraseology makes it difficult for students, since there are no equivalent expressions in their native language. Practice of teaching Russian language shows that first you need to study adjectives in the direct meaning, and then offer examples with phraseological units that contain adjectives. This will draw students ' attention to the direct and figurative meaning of adjectives. For example, a white shirt and a white dance. Special attention should be paid to phraseological units with an adjective component that are related to the history and traditions of the Russian people. Illustrative material will help students understand the meaning of the phrase..

\section{Conclusions}

To improve the use of phraseological units, you need to know their semantic and grammatical features well, since you can not replace words in phraseological units, you can not re-invent them. 
We believe that the work should be systematic and in every lesson, only then can we achieve success and help foreign (Chinese) students learn phraseological units.

\section{Acknowledgements}

The work is performed according to the Russian Government Program of Competitive Growth of Kazan Federal University.

\section{References}

A Chupryakova, O., S Safonova, S., \& A Votyakova, I. (2019). Syntax Phrase Models with a Modal Component in the Discursive Space of AP Chekhov. Research in Applied Linguistics, 10(Proceedings of the 6th International Conference on Applied Linguistics Issues (ALI 2019) July 19-20, 2019, Saint Petersburg, Russia), 612-619.

Azimov, E.G., \& Shchukin, A.N. (2009). New dictionary of methodological terms (theory and practice of language training). Moscow: Icarus. 448p.

Gok, E., Lukoyanova, Y. K., \& Brenchugina-Romanova, A. N. (2019). THE NOUN6 "CENTURY" IN N. YAZYKOV'S POETIC WORLD. Humanities \& Social Sciences Reviews, 7(6), 799-802.

Khodyakova, L.A. (2018). Methods of speech development of a student's creative personality in the context of culture: theory and practice: monograph.M.: Moscow state pedagogical University. 188p.

Mokienko, V.M. (2005). Riddles of Russian phraseology. Saint Petersburg: avalon, Azbukaklastika. $256 \mathrm{p}$.

Nurullina, G.M., Latfullina, L.G., \& Usmanova, L.A. (2019). The lexeme "sun" as an element of the figurative system of works by M.A. Sholokhov. Revista Inclusiones, 6 / Número Especial / Octubre - Diciembre, 766-771.

Rakhimova, D., Davlatova, M., \& Lagay, E. (2019). Linguistic bases of improvement of culturalspeech competence of Students on the material of expression of causal-investigative relations in the modern Russian Language. A d a l t a, 99 - 101.

Shakirova, A.A., Yusupova, Z.F., \& Gordienko, O.V. (2019). Development of creativity and linguistic-methodical thinking of students of pedagogical university. International Journal of Psychosocial Rehabilitation, 23(1), 163-169..

Telia, V.N. (2010). Bolshoy phraseological dictionary of the Russian language (fundamental dictionaries).Moscow: AST: Astrel.784 p.

Ter-Minasova, S.G. (2000). Language and intercultural communication. Moscow: Slovo.262 p.

Xiaoxu, W., A Hayrutdinova, G., \& Xinxin, Z. (2019). Nouns Gender and Number Aesthetic Potential in the Aspect of the Comic. Research in Applied Linguistics, 10(Proceedings of the 6th International Conference on Applied Linguistics Issues (ALI 2019) July 19-20, 2019, Saint Petersburg, Russia), 870-877.

Zabuga, A.A., Aleeva, G.H., \& Brenchugina-Romanova, A.N. (2018). Teaching the Russian language at the level of professional education as a linguo-didactic problem. National academy of managerial staff of Culture and Arts herald, 3, 860-862. 